\title{
MEMBERSHIP SUPPORTED LAW FIRMS: A RESOLUTION OF THE PUBLIC INTEREST LAW DILEMMA
}

Public interest law firms have been held out as ombudsmen ${ }^{1}$ that could represent interests in society that have been lost within the political process. This bright promise has obscured major structural faults. The claim that public interest law firms represent the public interest, and the financing necessary to ensure the continued existence of these firms, ${ }^{2}$ rest on an uncertain foundation. There is a solution to this dilemma. The promised protection for the legal rights of the politically impotent can be realized if particular minority interest groups form small membership supported law firms to represent their interests. This Comment examines the principal ethical and constitutional issues raised by the concept of a inembership supported law firm. As a model, a student supported law firm is examined in detail.

\section{$\mathbf{I}$}

\section{Structural Problems of Public Interest Law Firms}

Public interest firms do not represent the "public." A given firm may represent a particular group's interest ${ }^{3}$ or its attorneys' views of the public interest, ${ }^{4}$ but no public interest law firm is controlled by the

1. See R. NAder \& D. Ross, Action for a Change (1971); Cahn \& Cahn, Power to the People or the Profession?-The Public Interest in Public Interest Law, 79 Yale L.J. 1005 (1970); Comment, The New Public Interest Lawyers, 79 Yale L.J. 1069, 1070 n.3 (1970). An attorney working for Public Advocates Inc. argued specifically that public interest firms are America's ombudsmen. Interview with Robert Gnaizda in San Francisco, February 8, 1972.

2. The prospects for future foundation support are especially uncertain. Comment, supra note 1 , at 1114. Furthermore, if the firms become involved in politics, they may not be able to keep their favored tax status. See Note, Regulating the Political Activities of Foundations, 83 HARv. L. REv. 1843 (1970). The Internal Revenue Code provides for taxation of any funds expended by an otherwise tax exempt organization if the funds are used to influence legislation. INT. REv. CODE of 1954, $\S 4945$.

3. An example is the NAACP Legal Defense Fund, Incorporated. The Defense Fund is not a membership supported firm; an independent board controls it and solicits funds from the public at large.

4. Rohert Gnaizda, describing the founding of Public Advocates, said that the attorneys were responsible to their board of directors. He recognized, however, that the directors had been handpicked and that an important criterion in their selection was that they agreed with the attorneys that the problems of race relations and poverty are crucial. Interview with Robert Gnaizda, supra note 1 . The firm's case docket reflects the fact that the firm's attorneys are mainly interested in race relations. There were 23 suits filed as of January 25, 1972; 18 were directly concerned with race relations and poverty problems. Other suits had been filed in the areas of sex 
popular will. Existing firms are largely the progeny of reform-minded foundations and attorneys; their boards of directors are not chosen from the public, but from luminaries notable not for the diversity, but for the congruence of their views. ${ }^{5}$ And in their attempt to insulate themselves from political pressures the firms have further isolated themselves from the public. In fact, public interest law firms eschew government financing because such funding subjects them to pressures from popularly elected officials. ${ }^{b}$ Thus, there is little in the structure of existing public interest firms to support a claim to representation of the diverse American public.

For public interest law firms that depend on foundations for financial support there can be undesirable collateral consequences. For example, to the extent that a firm strives to show its sponsors that it can innovate, it may pursue projects that the public would just as soon not see realized. Furthermore, as long as the firms look to foundations for financing, groups within the community may bring informal pressures to bear on the firm.

Foundations generally provide "seed money," that will finance a firm only for several years. Consequently, public interest law firms have been looking to the courts for awards of attorneys' fees as a future source of income. ${ }^{7}$ This is one way to avoid the problems of foundation fimancing. Yet, to the extent that public interest firms rely on the courts for future funds, their ability to pursue certam types of important cases is likely to be circumscribed. The firm will have to cover the expenses of important suits that produce no court award by winning a number of lucrative suits. Indeed, unless the courts are generous with awards, the firm may turn away from bringing test cases at the frontier of the law or suits that will not pay for themselves. Instead, they may

discrimination and environment protection. Memorandum from J. Anthony Kline to the Board of Directors, Jan. 25, 1972, on file at Public Advocates, Inc.

5. A typical board of directors is that of the Center for Law and Social Policy. See Hearings on Tax Exemptions for Charitable Organizations Affecting Poverty Programs before the Subcomm. on Employment, Manpower, and Poverty of the Senate Comm. on Labor and Public Welfare, 91st Cong., 2nd Sess., at 227-28 (1970) [heremafter cited as Hearings].

6. See Hannon, The Murphy Amendments and the Response of the Bar-An Accurate Test of Political Strength, 28 Legal Aid BRIRFCASE 163 (1970); Holmes, The Poverty Lawyers' Work is so Good It Has to Be Stopped, WAsHInGton MoNTHLY, June 1970. Both discuss the potential for political reprisals against successful public interest groups. See also, Grant No. CG 7172, Program Year D, Program Account Number S57, Nos. 6(c) through 6(g) (1971), Office of Economic Opportunity, Special Conditions for the grant to California Rural Legal Assistance, [on file with the California Law Review] that placed limitations on the OEO grant to California Rural Legal Assistance League after a confrontation with Governor Reagan.

7. See text accompanying notes 51-59 infra. 
take only those suits that, because of the likelihood of a court award, a private attorney might have taken.

The more public interest law firms rely on court awards, the less analogous they are to traditional charitable groups that receive tax exemptions: firms supporting themselves by court awards are more like private firms specializing in class actions. ${ }^{8}$ The present grant of a section 501(c) (3) exemption to public interest law firms rests on two suppositions: first, that they litigate in the public interest; second, that they will not normally engage in litigation when the financial interests are such that the litigants could hire a private attorney. ${ }^{10}$ Under these circumstances the firms are likely, under present law, to lose their tax benefits if they rely on court awards for financing.

8. The private firm of Wickle, Atkinson, Boller and Falls in Los Angeles has specialized in class actions, which have coinprised a major share of their business for over ten years. Interview by telephone with David Boller at his office in Los Angeles, Nov. 8, 1971.

9. See Guidelines, News Release, Int. Rev. Service 1078 reprinted in Hearings, supra note 5 at $12-13$.

1. The engagement of the organization in litigation can reasonably be said to be in representation of a broad public interest rather than a private interest. The litigation is designed to present a position on behalf of the public at large on matters of public interest. Typical of such litigation may be class actions in the public interest, suits for imjunction against action by governinent or private interests broadly affecting the public, similar representation before administrative boards and agencies, test suits where the private interest is small, and the like. The activity would not normally extend to direct representation of litigants in actions between private persons where their financial interests at stake would warrant representation from private legal sources. In such cases, lowever, the organization may serve in the nature of a friend of the court.

2. The organization does not accept fees for its services except in accordance witli procedures approved by IRS.

3. The organization does not attempt to achieve its objectives through a program of disruption of the judicial system, illegal activity, or violation of applicable canons of ethics.

4. The organization files with its annual information return a description of cases litigated and the rationale for the determination that they would benefit the public generally.

5. The policies and programs of the organization are the responsibility of a board or committee representative of the public interest, which is not controlled by employees or persons who litigate on behalf of the organization nor by any organization that is not itself an organization described in Section 501(c) (3) of the Internal Revenue Code.

6. The organization is not operated, through sharing of office space or otherwise, in a manner so as to create identification or confusion with a particular private law firm.

7. There is no arrangement to provide, directly or indirectly, a deduction for the cost of litigation which is for the private benefit of the donor.

8. The organization inust otherwise comply with the provisions of Section 501(c)(3), that is, it may not participate in, or intervene in, any political campaign on behalf of any candidate for public office, no part of its net earnings may inure to the benefit of any private shareholder or individual, and no substantial part of its activities may consist of "carrying on propaganda, or otherwise attempting, to influence legislation".

10. Id. $\S 1$. 
Public interest firms are therefore faced with a dilemma. Foundation funding may be structurally undesirable and financially uncertain. Funding through attorneys' fees, while affording more independence and longevity, threatens the very purpose of such firms-to litigate cases private attorneys will not take-and inay threaten the firms' existence if their tax exempt status is lost.

II

\section{MEMBERShIP SUPPORTED LAW FIRMS}

All organizations are notivated by self interest to satisfy the goals of the body to which they look for their financing. ${ }^{11}$ While public interest firms have sought to hold themselves out as representing the public, foundation financing has resulted in foundation control of the choice of attorneys, boards of directors, and, indirectly, cases. An independent board of directors does not ameliorate the problem. At best, directors act in an advisory capacity. For example, if a recalcitrant board were to refuse to permit the staff to bring a particular action, and the staff had the support of the firm's sponsoring foundation, the staff could either force the directors to resign, or, with the support of the foundation, bring the suit independently.

On the other hand, a membership supported law finn has a board of directors elected by the inembership group that supphies the money to support the firm. The firm's legitimacy and continued economic vitality depends upon its winning the approval of its constituency. Rather than a liandpicked board of luminaries trying to decide what is in the public interest, the elected representatives of the membership msure that only those suits that are within the meinbership's interest are brought. The group's representatives can define the membership's interest, subject to being overruled in the next election. But the membership's interest does not necessarily have to be narrow self interest. The directors could conclude, for instance, that environmental issues are of primary importance to the members. Whereas a handpicked board would be guessing if they made such a judgment, the directors of a membership board are likely to have run on a particular platform, and if they do not in fact represent the members, they will not be reelected. The membership firm will realize that its financing depends not only on winning suits, but on winning those suits important to the group. For example, where the membership that supports the firm is largely senior citizens, if the firm were to specialize in student rights the

11. Cf. C. LeVi-Strauss, Structural ANthropology 21 (1963): "It is necessary and sufficient to grasp the unconscious structure underlying each institution and each custom, in order to obtain a principle of interpretation valid for other institutions and other customs, provided of course that the analysis is carried far enough." 
membership would be likely to soon abandon the firm even though the firm was successful.

Furthermore, to the extent that the firm relies upon membership fees for a substantial portion of its financing, it, unlike public interest firms subsisting on court awards, retains its resemblance, for tax purposes, to recognized charitable organizations. When the Internal Revenue Service threatened to lift its grant of tax exemptions to public interest firms, the Service was careful to note that this reevaluation was not intended to reach existing membership supported firms such as the American Civil Liberties Union. ${ }^{12}$ This solicitude suggests that when the IRS eventually rules on whether firms may receive court awards of attorney's fees and retain their tax exempt status, law firms funded largely by member contributions will be allowed ${ }^{13}$ to retain a 501 (c) (3) exemption.

Public interest law firms, including membership supported law firms, have been challenged on the ground that they encourage breaches of the ethical and legal proscriptions against conflict of interest and solicitation. The following subsections discuss these issues in detail and demonstrate that blanket proscriptions of legal solicitation and conflicts of interest should not be used to prohibit legal activity in the public interest and, in particular, that they slould not be applied to membership supported law firms.

\section{A. Legal Ethics and the Right to Litigate}

Traditionally, lawyers lave been paid by the party to whom the cause of action belonged. ${ }^{14}$ In this country, bar associations have strongly resisted lawyer-client arrangements in which the attorney looks

12. News Release, Int. Rev. Service 1078 reprinted in Hearings, supra note 5, at 11:

These proposed programs [public interest law firms] are frequently in support of the interests of a majority of the public, as distinguished from legal representation for a disadvantaged minority, such as the poor, the victims of racial discrimination, or those denied hunan and civil rights either in criminal or civil matters. Legal representation for the latter class has long been recognized as a charitable activity and the IRS has long ruled that organizations so engaged are exempt under Section 501(c)(3) of the Internal Revenue Code in accordance with judicial precedents. There is, however, no such clear set of precedents for the newer type of organizations. Therefore, it was necessary for the IRS to develop these guidehnes under which public interest law firms may obtain advance rulings on which contributors may rely.

13. See IRS Guidelines, supra note 9. To date the IRS has not established procedures by which a pubhic interest law firm can accept awards of attorney's fees without jeopardizing its tax exeinption.

14. See Ehrenzweig, Reimbursement of Counsel Fees and the Great Society, 54 CaLIr. L. Rev. 792 (1966); Ehrenzweig, Shall Counsel Fees Be Allowed? 26 CaL. ST. B.J. 107 (1951); Stoebuck, Counsel Fees Included in Costs: A Logical Development, 38 U. Colo. L. REv. 202 (1966); Note, Attorney's Fees: Where Shall the Ultimate Burden Lie?, 20 VAND. L. REv. 1216 (1967). 
to someone other than the person directly aggrieved-a lay intermediary-for the fee. ${ }^{15}$ They argue that an attorney hired by a third party, such as a inembership supported law firm, may be faced with conflicting loyalties. For example, an interest group representing a litigant may be interested in developing new legal theories to aid the group as a whole, while the particular litigant might best be helped by a traditional legal argument. ${ }^{16}$ Sinnilarly, a union member whose personal imjury claim is handled by the union attorney may find his particular claim compromised by the union attorney as part of a wholesale settlement of union claims against the particular company. ${ }^{17}$

Another objection to intervening lay third parties, like a legal services corporation or a meinbership supported law firm, is that, unlike attorneys, who are restrained by the Code of Ethics, the lay intervenor is free to stir up litigation. It has been argued that an intervening corporate body, or lay board of directors, is not bound by the

15. Bar associations not only represent society's intercst in insuring high professional standards but also the economic and political goals of their members. Bar imposed sanctions are subject to judicial review, and as a result, when the bar objects to a given program, their objection is always phrased in terms of the public interest, although the objection may be founded as much upon self interest as society's interest. See H. Drinker, Legal Ethics 167 (1953). See also Weihofen, "Practice of Law" by Non-Pecuniary Corporations: A Social Utility, 2 U. CH. L. Rev. 119 (1934); ILLINOIS STATE BAR Ass'N, ECONOMIC INSTITUTE HANDBOoK 3 (1960): "The respect for the legal profession and its influence in the individual cominunity will be raised when the lawyer occupies his proper place at the top of the economic structure," cited in Comment, Controlling Lawyers by Bar Associations and Courts, 5 HArv. Civ. Rights-Civ. LiB. L. Rev. 301,347 n.229 (1970).

The principal lower court decisions on intervening third parties are: In re Community Action for Legal Services, 26 App. Div. 2d 354, 274 N.Y.S.2d 779 (1966) (denying a corporate charter to a legal services program); Richinond Ass'n of Credit Men, Inc. v. Bar Ass'n, 167 Va. 327, 189 S.E. 153 (1937) (the hiring of attorneys by the association constituted an illegal practice of law, on the ground that the association was an improper intervening lay intermediary); compare People ex rel. Courtney v. Association of Real Estate Taxpayers, 354 Mll. 102, 187 N.E. 823 (1933). See also ABA CODE of Professional ResponsibILITY Nos. 2, 4, 5 and comments DR 2-103(D), 4-101(B), 5-107(B); Zimroth, Group Legal Service and the Constitution, 76 YALE L.J. 966 (1967).

16. The rule forbidding an attorney to represent conflicting interests is not new. It is based on the ancient admonition that "No individual can serve two masters." Individual lawyers, therefore, as well as courts, have a duty to avoid such conflicting relationships and representations.

Tucker, Ethics of Activism, 56 A.B.A.J. 851, 852 (1970), citing State v. Goode, 84 S.D. 369, 171 N.W.2d 733, 734 (1969). Such arguments are not fanciful. See, e.g., N.Y. Times, Feb. 1, 1970, at 23, col. 1 (a convicted draft evader claimed that he had been persuaded to resist the draft by his lawyer who told him that his would be an important draft case). But see Zimroth, Group Legal Service and the Constitution, 76 YALE L.J. 966, 976 (1967). The author noted that in his review of death penalty cases argued by the NAACP he found no instance where the individual's interests were subrogated to the organization's goals.

17. See United Mine Workers v. Illinois State Bar, 389 U.S. 217, 232 (1967) (Harlan, J., dissenting). 
Code and may pursue a course that would be unethical for an attorney. The bar is expecially concerned that these corporations would advertise for clients, which is considered unbecoming professional conduct tending to lower standards of legal ethics. ${ }^{18}$

Recent decisions indicate, however, that these arguments cannot be used to proscribe the legal activities of a membership supported law firm. In NAACP v. Harrison ${ }^{19}$ the Virginia supreme court had upheld the state proscription of the NAACP's method of enlisting clients for test cases under its improper solicitation of legal business statute. ${ }^{20}$ The record contained evidence that named plaintiffs in several NAACP suits had not known that civil rights test cases were being filed in their names until long after the fact. ${ }^{21}$ Their only contact with the cause of action was signing a blank form, which staff attorneys handed out at meetings, authorizing the use of their names as plaintiffs. When the case was appealed, under the name $N A A C P$ v. Button, ${ }^{22}$ a majority of the Supreme Court held that the NAACP litigation that sought to gam protection of the civil rights of its members was a form of political expression protected by the first amendment. ${ }^{23}$

Under current first amendunent analysis, legislation that regulates a protected activity may be attacked either on the ground that on balance a state interest sufficient to justify impingement on a protected activity $^{24}$ has not been slown or that the statute is overbroad or vague. ${ }^{25}$ The Court in Button found that the mere possibility of

18. The professional services of a lawyer should not be controlled or exploited by any lay agency, personal or corporate, which intervenes between client and lawyer. If such were permissible, it would permit the corporation or lay agency to do that which the lawyers could not do; namely, the solicitation of business.

36 A.B.A.J. 677, 684 (1950). Compare In re Ades, 6 F. Supp. 467 (D. Md. 1934); see also, ABA Comm. on Professional Ethics, Opinions, No. 148 (1935). Compare Gunnels v. Atlanta Bar Ass'n, 191 Ga. 366, 12 S.E.2d 602 (1940) (upholding and commending an offer by the local bar to represent people who had been victimized by local loan sharks) with People ex rel. Chicago Bar Ass'n v. Chicago Motor Club, 362 Ill. 50, 199 N.E. 1 (1935) (holding illegal an arrangement whereby the club paid the lawyers' fees of members in claims arising out of automobile accidents) and Hildebrand v. State Bar, 36 Cal. 2d 504, 225 P.2d 508 (1950) (one of the early union cases striking down a group legal services progran.)

19. 202 Va. 142 , 116 S.E.2d $55(1960)$.

20. VA. CODE ANN. $\S \S 54-74,54-78,54-79$, as amended by Acts of 1956, Ex. Sess., c.33 (Repl. Vol. 1958).

21. See NAACP v. Button, 371 U.S. 415, 450 (1963).

22. 371 U.S. 415 (1963).

23. Id. at $428-29$.

24. For an examination of first amendment balancing see the interesting exchange between Mendelson, On the Meaning of the First Amendment: Absolutes in the Balance, 50 CarIF. L. Rev. 821 (1962) and Frantz, Is the First Amendment Law?-A Reply to Professor Mendelson, 51 CaLIF. L. Rev. 729 (1963).

25. See Note, The Void-for-Vagueness Doctrine in the Supreme Court, $109 \mathrm{U}$. PA. L. REv. 67 (1960). 
harm to a litigant was insufficient to justify state prohibition of an activity protected by the first amendment; rather, the state nnust show "a serious danger . . . of professionally reprehensible conflicts of in. terest which rules against solicitation frequently seek to prevent."20 Using a balancing test, the Court reasoned that since a money recovery was not at stake, and since the aims of the organization were not in conflict with the aims of the litigants, the danger of a conflict of interest was not serious enough to warrant the state prohibition. ${ }^{27}$ The Court also weighed the interests of society in permitting the Association to hitigate. The Court noted that, "History has amply proved the virtue of pohitical activity by minority, dissident groups", ${ }^{28}$ and then went on to state:

The NAACP is not a conventional political party; but the litigation it assists, while serving to vindicate the legal rights of members of the American Negro community, at the same time and perhaps nore inportantly, makes possible the distinctive contribution of a minority group to the ideas and beliefs of our society. ${ }^{20}$

In the subsequent cases of Brotherhood of Railroad Trainmen $v$. Virginia ex rel Virginia State Bar, ${ }^{30}$ and United Mine Workers v. Illinois Bdr Association ${ }^{31}$ the Court extended this holding to include within first aunendment protection group legal service programs that have attorneys associated with or retained by the group in order to obtain reduced rates. ${ }^{32}$ This attempt to obtain reduced rates had been attacked by the bar as illegal solicitation.

The facts in the recent case, United Transportation Union $v$. State Bar, ${ }^{33}$ were so narrow that the Court could have reversed the lower court's opinion per curiam on the basis of United Mine Workers. As in United Mine Workers, the union in United Transportation had recommended selected attorneys to members and their families, and

26. 371 U.S. at 443.

27. The Court relied on NAACP v. Alabama ex rel. Patterson, 357 U.S. 449, 459 (1958), as support for the identity of interest argument, but in that case the Court was not assessing the possibility of a conflict of interest but merely granting the association standing to assert the claims of its inembers. See 371 U.S. at 461-62 (Harlan J., dissenting). For the history of the struggle over intervening third parties see Radin, Maintenance by Champerty, 24 CALIF. L. Rev. 48 (1935) and cases cited note 16 supra.

28. 371 U.S. at 431, citing Sweezy v. New Hampshire, 354 U.S. 234, 251 (1957); cf. DeJonge v. Oregon, 299 U.S. 353, 364 (1937).

29. 371 U.S. at 431.

30. 377 U.S. 1 (1963).

31. 389 U.S. 217 (1967).

32. See Zinnroth, Group Legal Services and the Constitution, 76 YALE L.J. 966 (1967).

33. 401 U.S. 576 (1971). 
the bar attacked this program, designed to protect members from high fees and incompetent counsel, as illegal solicitation. The Court used the case as an opportunity to express its displeasure that bar associations had continued to resist group legal service programs. In dismissing the arguments of the Michigan Bar, which sought to distinguish United Mine Workers, Justice Black, writing for the majority, noted that the complaint appeared to be "a plea for court protection of unlimited legal fees." ${ }^{34}$ At the conclusion of his opinion Justice Black wrote:

At issue is the basic right to group legal action, a right first asserted in this Court by an association of Negroes seeking the protection of freedoms guaranteed by the Constitution. The common thread running through our decisions in NAACP v. Button, Trainmen, and United Mine Workers is that collective activity undertaken to obtain Ineaningful access to the courts is a fundamental right within the protection of the First Amendinent. However, that right would be a hollow promise if courts could deny associations of workers or others the means of enabling their inembers to nneet the costs of legal representation. ${ }^{35}$

In sum, the Court has decided that when there is a reasonable identity of interest between the client and the intervening association the State may not impede group legal activity because of a inere possibility of a conflict of interest or the existence of the mere possibility of solicitation. While the strong identity of interest between the NAACP and its membership was crucial in Button, United Transportation makes clear that a mere purpose of banding together to lower the cost of legal services is now a sufficient identity of interest to insulate an association formed to secure legal services from being automatically condemned under statutes prohibiting solicitation or bar association rules governing ethics.

This is an eininently realistic approach: available remedies are sufficient to control individual breaches of the attorney-client relationship; $;^{36}$ blanket prohibition of certain kinds of legal associations should not be necessary to control unethical conduct. While some abuses inay go undetected, these undetected abuses are of small consequence when weighed against the benefits of permitting access to the courts for litigants who have hitherto been unable to afford justice.

The policy reasons advanced for lolding that NAACP litigation was protected by the first amendment also justify protecting litigation by a public interest or inembership supported firm. The majority in Button noted that while the NAACP was not a conventional political

34. Id. at 577-78.

35. Id. at 585-86.

36. See text accompanying notes $58-59$ infra. 
party, litigation by the NAACP vindicates the rights of individual blacks and, at the same time, makes a distinct contribution to social and political thouglit. ${ }^{37}$ Similarly, a public interest or membershipsupported law firm does not take cases primarily to advance the claim of an individual litigant, but to use the case to advance the group's interest in broad social issues.

After United Transportation it is apparent that the fear that lay intermediaries, in this case the member supported firm, will stir up litigation, or engage in what would be improper solicitation if done by an attorney does not warrant broad proscriptions of a group's legal activities. Sanctions may be imposed only against groups wliose activities luave in fact violated a given canon of ethics. ${ }^{38}$ A sufficient identity of interest between the individual litigant and the firm must be slown, lowever, before it can be said, as in United Mine Workers, that the danger of baseless litigation or conflict of interest is too speculative to justify a broad state prohibition. ${ }^{39} \mathrm{~A}$ membership firm is responsible to an interest group and if necessary, the court may determine if the group's goals are consonant with those of the litigant. At most, only the problem of a possible compromise of the individual's interests, as the attorneys strive for the long-range purposes of the group, remains; the Button case and its progeny lave made clear that the mere possibility of sucli a conflict will not warrant preventing the group from being represented.

\section{B. Court Awards, Conflicts of Interest and Membership Supported Law Firms}

While a nnembership supported firm is within the protection of Button and its progeny, ${ }^{40}$ a more difficult issue is whether Button would protect a membership firm that looked mainly to awards of attorneys' fees for financial support. ${ }^{41}$ Button rested on the proposition that because of the identity of interest between the chients (poor blacks) and the

37. 371 U.S. at 431.

38. See NAACP v. Button, 371 U.S. 415, $438-45$ (1963).

39. 389 U.S. at 223. The Court found the case indistinguishable from Trainmen, even though the attorney was paid by the union, not merely recommended by the union as in Trainmen. In both situations, according to the Court, the attorney is economically dependent on the union, and there is no difference in the probability that an attorney would sacrifice the best interest of the client. Further, the Court found that there was no evidence that the theoretical schism between the interests of union and member ever occurred in a law suit. Id. at 224.

40. See text accompanying notes 19-35 supra.

41. Several New York attorneys are organizing a corporation that will issue shares to the public, hoping to pay dividends from awards of attorneys' fees arising from successful suits against polluters and consumer defrauders. The Anti-Corporation, Newsweer, Nov. 29, 1971, at 93-94. This type of firm poses somewhat different problems than the membership supported firms discussed here. 
lay intermediary (the NAACP) subordination of the clients' interest to a goal of the lay intermediary was not sufficiently probable to warrant a total proscription of NAACP litigation. When, however, a lay intermediary's financing comes not from a group having an identity of interest with the client, but from the courts, the crucial element in the balance struck by Button is missing. Any membership supported law firm that finances itself in part through court awards could thus conceivably be threatened with a state prohibition once the protective shield provided by Button is removed.

After Button, however, the Supreme Court specifically referred to the right of a group to associate to litigate as a fundamental right. ${ }^{42}$ As such, any statute seeking to differentiate between law firms according to the proportion of their income that connes from court awards might fall under an equal protection argument. If the right to litigate is fundamental, the state must be able to show that any exclusions are based on a compelling state interest. ${ }^{43}$ The criteria for the first amendinent are clear: a court should strike down any legislation tending to impair a first amendment right where a compelling state interest is not shown, or when the statute is either overbroad or under inclusive, or when less restrictive alternatives are available. ${ }^{44}$ There are important state interests on both sides of this problem. On the one hand, the state wants to protect its citizens froin being harmed by unscrupulous attorneys; on the other, the state has an interest that its citizens be able to vindicate their rights through its courts.

It is well known that many people find it difficult to vindicate their rights. A study conducted by the Missouri Bar, for example, found that only 3 percent of consumers would turn to a lawyer if they were defrauded. ${ }^{45}$ One commentator has explamed this as a failure to recognize legal problems.48 A better explanation, perhaps, is that in fact for inany consumers' problems there have not been remedies; people far from being unaware of their rights have been fully aware that they had no legal redress. ${ }^{47}$ And there is no redress either because these people cannot afford a lawyer or the cost of an attorney would be greater than any possible recovery.

42. See text accompanying note 35 supra.

43. Kramer v. Union Free School Dist., 395 U.S. 621 (1969); Williams v. Rhodes, 393 U.S. 23 (1968) (right to associate analyzed as fundamental).

44. See Frantz, The First Amendment in the Balance, 71 YALE L.J. 1424 (1962).

45. See D. Caplovitz, The Poor Pay More 175 (1963).

46. See Comment, Controlling Lawyers by Bar Associations and Courts, 5 HARv. Civ. Rughrs-Civ. LIB. L. Rev. 301, 353 (1970).

47. This is the author's observation after two years as a community organizer in VISTA. 
In response to these problems both the courts and the legislature have begun to provide for awards of attorneys' fees, ${ }^{48}$ to broaden the concept of standing ${ }^{49}$ to permit challenges to admimistrative decisions and to interpret liberally the rules permitting class actions. ${ }^{50}$ Having balanced the benefits of encouraging litigation against the detriments of possible abuses of the attorney-client relationship, the legislatures and the courts have thus been gradually opening up the legal process. As a result, there are now private firms that subsist on awards of attorneys' fees in class action suits. ${ }^{51}$ Membership supported law firms also grew out of this effort to increase access to the courts for those who before were unable to obtain legal redress for their problems. Since these firms are a child of the state effort to open up the legal process, the state interest in favor of their preservation should be strong.

Furthermore, the taint of commercialism is not fatal to the exercise of the first annendunent right to litigate, nor does the finding of a profit motive justify the regulation of the activity for just any rational purpose. $^{52}$ In New York Times $v$. Sullivan ${ }^{53}$ for instance, the Court held that the alleged libel was no less protected by the first amendment just because it was a paid advertiseinent. But while a commercial motive may not be fatal, it may raise the possibility of a conflict of interest and tip the scales towards permitting the state to prohibit the activity..$^{54}$

48. See, e.g., Annot., 8 L. Ed. 2d 894 (1962); Annot., 39 A.L.R.2d 580, 583-84 (1955). The most interesting recent case is Mills v. Electric Auto-Lite Co., 396 U.S. 375 (1970), which is discussed in Note, The Allocation of Attorney's Fees After Mills v. Electric Auto-Lite Co., 38 U. CHI. L. Rev. 316 (1971). For a typical example of the phrasing of an authorization of attorney's fees by Congress, sec Title II of the Civil Rights Act of 1964, 42 U.S.C. $\S 2000$ (a)(3)(b) (1964).

49. See, e.g., Comment, Conservationist's Standing to Challenge the Actions of Federal Agencies, 1 EcoL. L.Q. 305 (1971); Office of Communication of the United Church of Christ v. Federal Communications Comm'n, 359 F.2d 994 (D.C. Cir. 1966). This decision granted standing to the church in hearings before the FCC on whether a hicense should be reissued to a radio station that, it was alleged, was not responsive to the needs of racial minorities in its community.

50. Fed. R. Civ. P. 23. See e.g., Ford, Federal Rule 23: A Device for Aiding the Small Claimant, 10 B.C. IND. \& CoM. L. REv. 501 (1969); Starrs, The Consumer Class Action-Part I: Considerations of Equity, 49 Bost. U. L. Rev. 211 (1969). See also Eisen v. Carlisle, 391 F.2d 555, 563 (2d Cir. 1968) (holding that Rule 23 is to be interpreted liberally); Green v. Wolf Corp., 406 F.2d 291 (2d Cir. 1968), cert. denied, 395 U.S. 977 (1969).

51. See note 8 supra.

52. If a first amendinent freedoin is involved the Court will not show the deference to a legislative decision that it pays when an econounic interest is threatened. Compare Railway Express Agency, Inc. v. New York, 336 U.S. 106 (1949) with Freedman v. Maryland, 380 U.S. 51 (1965).

53. 376 U.S. 254 (1964).

54. See NAACP v. Button, 371 U.S. at 470 n.17 (Harlan J., dissenting). 
Membership supported law firms financed partly by court awards are much like lawyers on a contingency fee. Both have a stake in winning the case and not settling it out of court for a small amount after imvesting a good deal of time and effort developing the suit. Lawyers are permitted to accept contingency fees because this allows the assertion of meritorious claims that otherwise would not be brought because the client cannot afford to have an attorney. ${ }^{55}$ Similarly, nember supported firms, or private firms that specialize in class actions, make it possible for groups not otherwise able to afford it to bring their clainns to court. Thus, the possibility of ethical problems should be no greater for membership supported firms than for lawyers on a contingent fee.

Having weighed the state interests for and against member supported firms subsisting on court awards and having considered if the statute is overbroad or underinclusive, a reviewing court must also consider if less restrictive alternatives to a complete prohibition of these firms are available. ${ }^{56}$ First, as supervisor of disciplinary proceedings, the court can consider that an attorney working for a inembership supported firm is bound by the Canons of Ethics not to permit the goals of the organization to prejudice the handling of his chient's interest. $^{57}$ Furthermore, the court is certain to be alert to individual abuses, and is fully able to protect the litigant or the class when it detects its best interests are not being served by the attorney. ${ }^{58}$ And last, if an attorney has dealt unfairly with his chient, he is liable under traditional tort doctrines for malpractice. ${ }^{59}$ The courts therefore have a variety of well settled, familiar approaches that they may use to prevent abuses of the attorney-client relationship. Aware that they

55. See ABA Special Committee on the Avaldability of Legal Services, RECOMMENDATIONS 17 (1968) which rejected the conflict of interest argument in group legal service situations.

56. See NAACP v. Button, 371 U.S. $415,438$.

57. See ABA Comm. on Ethics and Professional Responsibility, Opinions No. 324, 1 (1970). The opinion holds that the governing board of a legal aid society has the right to establish operational policy but it must guard against interference with specific cases or the representation of some clients by staff attorneys. See also aba Canons of Professional Ethics Nos. 6, 8, 15, 35, 37; ABA Code of ProFESSIONAL RESPONSIBILITY Nos. 2, 4, 5 and DR2-103(D)(1), DR4-101(B)(1), DR5107(B), and EC 2-25, EC 2-27, EC 2-28, EC 4-2, EC 5-1, EC 5-21, EC 5-23, EC 5-24.

58. See Rothman v. Gould, 52 F.R.D. 494 (S.D.N.Y. 1971). In a recent Calfornia case, La Sala v. American Savings and Loan Ass'n, 5 Cal. 3d 864, 489 P.2d 1113, 97 Cal. Rptr. 849 (1971), the court held that the lower court had the power to permit an attorney who had filed a class action to amend his complaimt and substitute a new plaintiff when the original representative of the class settled with the defendant out of court. (1959).

59. See Wade, The Attorney's Liability for Negligence, 12 VAND. L. REv. 755 
have the power to control abuses, the courts should encourage awards of attorneys' fees to membership supported firms.

\section{III}

\section{Student Supported LaW Firms: A Model Constituency}

For the past several years students have developed a growing interest in environmental and consumer issues and have become aware of the impact lawyers have made on these areas. Heightened interest in these problems has resulted in a movement for student support of public interest research groups and public interest law firms. ${ }^{60}$ Ralph Nader has been important to this movement, first by developing the concept of the membership supported law firm $^{01}$ and second by personally nourisling fledgling student programs. The University of Oregon was the first to establish a public interest research group ${ }^{02}$ and has been swiftly followed by universities in Minnesota, Georgia, Illinois and Connecticut. ${ }^{63}$

A large university student body in many ways is an ideal constituency for a membership supported láw firm. As a group students have many shared interests and are organized, at least minimally, with a student government and a campus paper. And if enough students at a large university contribute a few dollars, perhaps as an addition to registration fees, a substantial amount of money can be raised. ${ }^{84}$ The university has three maim purposes: education, research and public service. ${ }^{65}$ A student-supported firm will naturally tie itself to these

60. There are two major works on student firms: R. NADER \& D. Ross, Acrion for a Change (1971); and P. Decker, Student Supported Public Interest Law FIRMS: FROM THE GROUND UP (1971). at 86.

61. See, Ralph Nader Becomes an Organization, Business WeEK, Nov. 28, 1970,

62. Mr. Nader has preferred to call his organizations public interest research groups, perhaps to indicate that they are not only involved in litigation, but also in developing information to be released publicly to pressure their targets into making changes without the need for lititgation.

63. Ralph Nader Becomes an Organization, BusiNess WeEk, Nov. 28, 1970, at 86-87.

64. See R. NADER \& D. Ross, supra note 60 at 34.

65. See T. Cunningham, General Counsel of the Regents of the University of Califormia, Memorandum on Mandatory Student Fee for Center For Public Interest Law, Nov. 5, 1971. The memorandum was prepared in response to attempts to establish a membership supported law firm at the University of California Berkeley. It states:

The proposed activities of the Center for Public Interest Law would afford the participating students some incidental educational opportunities. Still, the Center is an outside organization maintained primarily for non-University social action purposes. Hence, I must conclude that the University cannot validly impose a mandatory student fee to be used for the support of the Center. 
purposes and to its constituents, offering them numerous educational research activities; im return, the firm will perform a public service by bringing important issues before the public through its reports, and before the courts through its litigation. ${ }^{66}$ The following subsections demonstrate that it is within the power of the governors of either a pubhic or private university to permit their students to be assessed to finance a meinber supported law firm.

\section{A. The Discretion of the Governors of a University}

A state university is a state instrumentality and must act in accordance with its charter, and the state and federal constitutions. ${ }^{67}$

Memorandum at p. 2. Compare, Memorandum in Response to General Counsel's, Dec. 7, 1971. The memorandum notes that the General Couusel had failed to cite a single authority in support of his conclusion. It then argued that the General Counsel had assumed the power to make a policy decision when the California Constitution vests this power in the regents. After discussing the authorities, the memorandum states: "The question of law, is, then, not whether Mr. Cunningham thinks that the center is within the scope of the University's purposes, but rather, would a court find that the Regents were uureasonable if they were to decide that the Center was within the scope of the University's purpose?" Memorandum in Response at p. 4. The response then discusses the inerits of the program, arguing that not only was the Center consonant with the University's purposes, but that in fact it was much more closely tied to traditional education than many community-mvolvement programs which were being fuuded from student fees.

In his Memorandum of January 7,1972 , the General Counsel reversed himself, stating that it was his opinion that this was a questiou for the regents to resolve. Memorandum re: Center for Public Interest Law-Mandatory University Student Fees, from T. Cunningham to R. Johnson, Jan. 7, 1972. All inemoranda are on file with the California Law Review.

66. A number of objections were raised by both administration officials and the regents when students attempted to establish a law firm funded with student fees at the University of California Berkeley. First it was argued that the firm would not be within the purposes of the university. In response, proponents pointed to the variety of programs that are currently funded by the university, for example, yell leaders, voter registration, draft help, a student lobby in Sacramento and female liberation. In addition it was argued that significant educational purposes would be served by involving students within the firm's research. A second argument made by the opponents was that the firm might bring suit against the university. The organizers felt that there were more important objectives for the firm, and as a price for university cooperation, were willing to guarantee that it would not sue the university. The strongest argument against the firm is that the university has lost prestige lately and if the firm became controversial it would be yet another burden that the university must bear when asking the legislature for money. The response was that, on balance, the people of California have shown that they will support responsible cousumer and environmental advocacy and that ultimately the firm will be an asset to the university. See Memoranda cited note 65 supra. After a two-year struggle, the regents rejected the refundable fee proposal. See San Francisco Chronicle, July 15, 1972, at 8, col. 3.

67. E.g., Hamilton v. Bd. of Regents, 293 U.S. 245 (1934). Rather than deal with particular problems which flow from the grant of power, whether contained in the state constitution or a private charter, this Comment addresses the common questions of law. 
The first inquiry, therefore, is whether the initial grant of power to the university permits it to impose a fee used to fund a membership firm. The law relating to the powers of a university governing board is well established. Generally, the directors of a university have the power to enact whatever regulations are necessary to govern a university, as long as the act is not prohibitcd by statute or the Constitution. Thus, in State ex rel Priest v. Regents of the University of Wisconsin, ${ }^{08}$ the university imposed a fee to pay for the utility costs on the physical plant of the scliool, in the face of a statute forbidding tuition fees. When a student challenged the fee, the court distinguished it from a tuition fee and then went on to say that the university charter grants the power to "govern" a university and to "enact laws" for that purpose. $^{69}$ Furthermore, the court reasoned that the closest analogy to the grant of power to the university is the grant of power to a business found in its corporate charter, holding that like a corporation a university had the implied power to use any reasonable means to achieve the goals outlined in its charter. ${ }^{70}$ Similarly in Connel v. Gray ${ }^{71}$ a state court upheld a student fee used to compensate the university for extraordimary property damage. The clear implication of these cases is that a state university has broad powers to assess fees to support the functioning of the institution.

But the authority to assess fces is not limited to the financing of necessities. In Rheam v. Board of Regents, ${ }^{72}$ for example, the students of the University of Oklahoma voted to assess themselves to finance the building of a student union to be incorporated under their separate control. The regents of the university approved this fee. When it was challenged by a student the court held that it was "not required to look for grants of power to the Board of Regents of the University, but for limitations on its power."

In most cases, therefore, the governors of a university can find a sufficient grant of power to do that which they feel is within the university's purposes. The courts will not interfere so long as the university's act is not specifically prohibited by the authorizing statute or the Constitution. ${ }^{74}$

68. 54 Wis. 159,11 N.W. 472 (1882).

69. Id. at $166-69,11 \mathrm{~N} . \mathrm{W}$. at $475-76$.

70. Id. at 170,11 N.W. at 477.

71. 33 Okla. 591, 127 P. 417 (1912). The court struck down that portion of the fee that would have been used to support the Young Mens' Christian Association program as unconstitutional state support of rehigion.

72. 161 Okla. 268, 18 P.2d 535 (1933).

73. Id. at $271,18 \mathrm{P} .2 \mathrm{~d}$ at 539 .

74. The California authorities are in accord with the general principles discussed above. The first California supreme court case to discuss the relation of the regents to the University of California is Estate of Royer, 123 Cal. 614, 56 P. 461 (1899), 


\section{B. Constitutional Considerations \\ When a Public University Collects a Fee \\ for a Student Supported Law Firm}

\section{Mandatory Student Contributions}

The use by a public university of student registration fees to support a law firm raises a substantial first amendment problem that has never been resolved by the Supreme Court. A student who is compelled to contribute to the firm as a condition precedent to registering at a public university might argue that he is being forced to associate with the law firm and that a mandatory contribution in effect implies his approval of the group's activities.

Support of a law firm involves different considerations than student support of a more typical activity such as a student union or a tutorial project. While a member supported law firm that has qualified for a 501(c)(3) tax exemption cannot fairly be characterized as a partisan political activity, ${ }^{75}$ it certainly is a mode of political expression. $^{78}$ The first amendment guarantee of free speech demands that the state not condition access to a public service upon compromise of one's right to hold certain political views openly, unless an overwhelming state interest, such as the national security, is shown. ${ }^{77}$

which rather narrowly held that the regents "have no duties or powers beyond the purpose of their creation, which was to take the custody and control of the university property, and to perform certain prescribed duties in the management of the university." Id. at 622,56 P. at 464 . In the subsequent decision of City Street Improvement Co. v. Regents of the University of California, 153 Cal. 776, 96 P. 801 (1908), the court indicated its willingness to decide the limits of the educational purposes of the university when it held that certain land might be assessed for street improvements inasmuch as it was not being held for edncational purposes. The court of appeals expanded the holding of Royer in Williams v. Wheeler, 23 Cal. App. 619, 138 P. 937 (1st Dist. 1913), and elevated the university to a special status within the state government noting deference was to be paid to decisions of the regents, except in the most unusual circumstances. The case pernitted the regents to order all students to be vaccinated while the authorizing statute permitted those who were conscientiously opposed to be excused. In the most recent case, Goldberg v. Regents of the University of California, 248 Cal. App. 2d 867, 57 Cal. Rptr. 463 (1st Dist. 1967), arising out of the Filthy Speech Movement, the court of appeals refers to the regents as having "full powers" so long as they are acting within university purposes.

75. Statement of Randolph W. Thrower, Commissioner of Internal Revenue Service, reprinted in Hearings, supra note 5 at 54-83. See the memorandum prepared by Mitchell Rogoven, attorney for the Center for Law and Society, setting out a strong argumeut for special tax trcatınent for public interest firms. Id. at 137-193.

76. See NAACP v. Button, 371 U.S. 415,431 (1963).

77. Cf. Shelton v. Tucker, 364 U.S. 479 (1960) (state cannot condition public teacher's job upon his disclosing the names of any groups of which he is a nember). See Van Alstyne, The Demise of the Right-Privilege Distinction in Constitutional Law, 81 HARV. I. REv. 1439 (1968). 
Most of the appellate court cases relevant to this subject have concerned either the right of a union to compel a member to pay dues when these are to be used for pohtical purposes, or the right of the state to condition practicing law upon nembership in a bar association engaged in lobbying activities. Both the bar association and the union fees are analogous to a mandatory student registration fee at a public university. The state is openly involved with the university and the bar, and, by implication with a union because of the extent of its regulatory activities. More important, if a required fee is not paid the individual will be denied access to important public commodities: a state-provided education, the practice of law, or a job. In each instance, there is a nexus of the first amendment rights of association and freedon 1 of speech: if a court were to find either that there was a compelled affirmation of behef, or forced association, it would have to strike down the fee exaction unless there lias been a showing of a compelling state interest. ${ }^{78}$

Typical of the cases is DeMille v. American Federation of Radio Artists $^{79}$ (AFRA). In 1944, Cecil B. DeMille was assessed $\$ 1.00$ by the union to support its fight against a "closed shop" proposition on the California ballot. AFRA controlled the radio unions and, after DeMille refused to pay, the union attempted to suspend his membership, which would have meant his loss of a $\$ 98,200$ a year job. The California supreme court decided in 1947 that the union could properly expel a niember who failed to pay an assessment that would have been used to promote the union's political view, so long as the issue was directly related to the union's purposes. ${ }^{80}$ The court treated the union as a voluntary association and argued that it was well known that majority rule prevailed. According to the court, it was incorrect to characterize the assessment as a compelled affirmation of belief. Analogizing the union to a government, the court stated,

In a government based on democratic principles, the benefit as perceived by the majority prevails. And the individual citizen would raise but a faint cry of invasion of his constitutional rights should he seek to avoid his obligation because of a difference in personal views. ${ }^{81}$

Although the United States Supreme Court has had a number of opportunities to consider the constitutional issue raised in the DeMille case, a majority of the Court has consistently been unwilling to decide if the exaction of a compulsory fee used for political purposes by an or-

78. See authorities cited note 24 supra.

79. 31 Cal. 2d 139, 187 P.2d 769 (1947).

80. Id. at 146,187 P.2d at 774 .

81. Id. at $150,187 \mathrm{P} .2 \mathrm{~d}$ at 776 . 
ganization closely tied to the state violates the first amendment. Several cases have come close to deciding this question. In United States $v$. $\mathrm{ClO},{ }^{82}$ the Court interpreted the 1925 Federal Corrupt Practices Act, ${ }^{83}$ as amended by Section 304 of the Labor Management Relations Act, as not preventing a union from using members' dues to pay for an endorsement of a candidate for Congress in the union magazine, commenting that if the law had intended that result that there would be serious doubt about its constitutionality. ${ }^{84}$ Four members of the Court were not as willing to construe the Act this way, however. Reaching the constitutional issue in a strong concurring opinion, Justice Rutledge reasoned that curtailing the ability of a union to speak on matters relevant to its members would violate the right of the members to associate freely im order to express their views. ${ }^{85} \mathrm{He}$ argued that, to the extent protection of minority dissenters was an issue, it would be sufficient to allow dissenters to file an objection to the expenditure of their dues for a given project and the union would then not apply their dues to that project. $^{86}$

The Court again faced the problem of compulsory fees and union membership in the Railway Employees Department v. Hanson ${ }^{87}$ in 1956. Again a majority of the Court refused to reach the constitutional question of what limits there are upon the expenditure of fees collected by a union bound by the first amendment because it operates under federal law. The Court found the constitutional issue not properly presented, and held that the Railway Labor Act authorized the union to exact dues to support the collective bargaining program of the union. ${ }^{s s}$ It did not decide whether compulsory union membership and assessinents impair freedom of expression.

The result of the Hanson decision was that another case with a better record was brought in International Association of Machinists $v$. Street. $^{89}$ The lower court found it unconstitutional for a union to use fees to support political causes a member opposed. ${ }^{30} \mathrm{~A}$ majority of the Supreme Court again refused to consider the constitutional question, however. Choosing a strained construction, ${ }^{91}$ the Court leld that the Railroad Labor $\mathrm{Act}^{22}$ prohibited assessment of a fee that

82. 335 U.S. 106 (1948).

83. Labor Management Relations Act, ch. 120, § 304, 61 Stat. 159 (1947).

84. 335 U.S. at 121.

85. Id. at 129 .

86. Id. at 149 .

87. 351 U.S. 225 (1956).

88. Id. at 238.

89. 367 U.S. 740 (1961).

90. Id. at 744-45.

91. See Id. at 799 (Frankfurter J., dissenting).

92. Railway Labor Act, 45 U.S.C. § 152 (1951). 
would be used in part for political purposes over a members objection..$^{93}$ The case is most interesting because the statute did not provide a remedy for an individual objecting to the use of his dues for a particular political project, yet the Court suggested alternatives. The Court, without citation, drew upon Justice Rutledge's argument in the $C I O$ case $^{94}$ Five members agreed that a blanket mjunction prohibiting the union from collecting all fees when part were to be used for political purposes was overbroad, since a majority of the union members lias "an interest in stating its views without being silenced by the dissenters." 95 The Court held that dissent was not to be presuned, but that the union should be permitted to collect the dues. If a member objected he could come forward and object to the assessment at which point the union could be restrained from spending his money on the political program or could be ordered to refund that portion of his dues that were spent upon the program.90

Subsequently, in a similar fact situation in Brotherhood of Railway Clerks v. Allen, ${ }^{97}$ the Court again avoided the constitutional issues and resorted to a statutory argument. Agam it suggested that each objecting union member must come forward and state his objection. If the union then failed to refund the portion spent on the objectionable political activity, a court could order the union to cease collecting from the member a proportion of his dues equal to that portion of the union's budget allocated to the prograin. ${ }^{98}$

The cases deciding the constitutionality of mandatory bar associations dues are no more clear cut. In the leading case of Lathrop $v$. Don$a h u e^{99}$ plaintiff objected to paying compulsory annual dues exacted as a condition precedent to practicing law in Wisconsin. The dues in part went to support the lobbying activities of the bar association. As in Hanson and Street, the Court refused to reach the freedom of speech question. It did hold that the exaction of a fee, when the meinber was

93. Four Justices construed the statute to prohibit such fees and a fifth reached the same conclusion on constitutional grounds. The statutory construction of the majority was criticized by Justices Black, Frankfurter and Harlan, 367 U.S, at 780-819. Justice Douglas who reached the constitutional question decided that such an exaction was unconstitutional and concurred as to the remedy, Id. at 775. Justice Whittaker, a member of the majority, disagreed as to what was a proper remedy, Id. at 779 . In addition, Justice Black considered forced political contributions a violation of the first amendment, Id. at 790, while Justices Frankfurter and Harlan found no first amendment objections so long as the individual remained free to express his own views, $I d$. at 818 .

94. See text accompanying notes 82-86 supra.

95. 367 U.S. at 773.

96. Id. at 774-75.

97. 373 U.S. 113 (1963).

98. Id. at $120-22$.

99. 367 U.S. 820 (1961). 
not compelled to vote or attend meetings, was not a violation of the first amendment guarantee of freedom of association. ${ }^{100}$ Using a balancing test, ${ }^{101}$ the Court reasoned that the exaction of a fee was a minimal burden on association, against which it weighed the interests of the state in using the integrated bar as a mechanism to protect ethical standards. ${ }^{102}$ While the Court did not hold that a inandatory fee could never be a violation of the right to freedom of association, in liglt of the strong arguments of the Court and Justice Harlan in his concurring opinion $^{103}$ and the previous union cases, it would be a rare fee that would be found unconstitutional, on freedom of association grounds.

Certainly when the minimal association that is deinanded by a university when it exacts nothing more than the payment of a fee to support a meinber supported law firm is weighed against a determination by the regents of the university that sucli a prograin will provide siguificant educational benefits, it would be most unlikely that a court would strike down the fee on freedom of association grounds. Whether a court would find a compulsory fee invalid as an infringement of freedom of speech is still an open question, however.

\section{The Use of a Refundable Fee to Finance a Student Supported Law Firm.}

While the Supreme Court lias refused to declare that an association, in part supported by a state, may not exact a compulsory fee to be used in part for political purposes, it would not be surprising if it were to do so $i m$ the future. As the railroad cases discussed above indicate, the Court has not decided whether it is constitutional for a group that is closely tied to the state to assess a compulsory fee for political purposes. However, both International Association of Machinists v. Street ${ }^{\mathbf{1 0 4}}$ and Brotherhood of Railway Clerks v. Allen ${ }^{105}$ intimate that a refundable fee is constitutional. For over 20 years the Court has thus been suggesting a refundable fee as a means of serving the legitimate need of the majority of an organization to use the association as a base for collective expression, while protecting a dissenting member from having to support a program to whicl he is opposed. ${ }^{106}$ Therefore, if a court were to

100. Id. at $843-48$.

101. Id.

102. Id. at 839-42.

103. Justice Harlan listed and rejected the appellant's counter arguments: 1. Reduction in economic capacity to espouse views; 2. Establishment of political views; 3. Development of a guild system; 4. Drowning out the voice of dissent; 5. Coinpelled affirmation of belief. Id. at 851-61.

104. 367 U.S. 740 (1961).

105. 373 U.S. 113 (1963).

106. See text accompanying notes 93-96 supra. 
decide that a membership supported law firm represented a form of political activity, a state supported university could find strong support for the constitutionality of refundable registration fees used to support the firm.

This position derives from the recognition that the majority should be allowed to state its views without being silenced by the minority. ${ }^{107}$ A refundable fee is an appropriate way to assure that, while a majority may use the resources of an organization to advocate positions relevant to the organization's purpose, minority members with strong convictions will not be forced either to pay and thereby to go against their consciences, or to withdraw from the association. Several as yet unarticulated factors also favor the refundable fee formula. Although the Court has not yet lield that a compulsory assessment warrants constitutional prohibition, ${ }^{108}$ a compulsory fee exacted to support political views with which one disagrees is a troublesome concept. Furthermore, if a membership supported law firm at a state university were supported with a compulsory fee it might look as if the state were taking a partisan position, or even brimging the suit itself.

If a student supported association is forced to rely on completely voluntary contributions, however, it may find that few are willing to make a voluntary contribution..$^{109}$ On the other hand, it is unlikely that a majority of the membership would withdraw from a refundable fee program. A viable student-supported research group or public interest law firm would require a rehiable source of funding that a refundable fee would provide. Thus, even though it would be at least arguably constitutional to assess the students of a public university on a compulsory basis, a refundable assessment would be wiser: it is likely to be a reliable source of funds sufficient to support the program while not raismg constitutional doubts.

\section{Membership Supported Law Firms at Private Universities}

Where there is no question of state action, private associations may assess their meinbers to support a public interest firm. The pow-

107. See Developments in the Law-Judicial Control of Actions of Private Associations, 76 HARv. L. REv. 983, 996 (1963).

108. See text accompanying notes 74-105 supra.

109. Rauh, Legality of Union Legal Expenditures, 34 So. CAL. L. Rzv. 152, 153 (1961). The author cites the testimony of Jack Kroll and James L. McDevitt, co-directors of COPE, a labor lobbying organization, [Hearings Before the Subcomm. on Privileges and Elections of the Senate Comm. on Rules and Administration, 84th Cong., 2nd Sess., part 1 at 45-64 (1956)] where the co-directors discuss the difficulties their unions have had raising money from members by voluntary contributions. On the other hand a private association, The Connecticut Citizen Action Group, reported in their newspaper that they had raised over $\$ 50,000$ in small contributions for a public interest firm. The Network News, Dec. 1971, at 2. 
er of a private association, however, is by no means unchecked: it may not require of its members that which is illegal, ${ }^{110}$ contrary to public policy, ${ }^{111}$ or unrelated to the purposes of the association. ${ }^{112}$ Inasmuch as supporting a public interest firm is neither illegal, nor contrary to public pohicy, ${ }^{113}$ a court would only strike down such an assessment if it were to find that the support was beyond the purposes of the organization. It is difficult to imagine an association of sufficient size to undertake support of a membership supported law firm that could not find some way of characterizing its action to encompass the firm within its purposes. Private associations are given wide latitude to interpret their charters, ${ }^{114}$ and can always modify their rules to permit such support. ${ }^{115}$

Similarly, a group organized as a corporation may support a law firm so long as it could characterize such support as consonant with its articles of incorporation. For example, in A.P. Smith Manufacturing Co. v. Barlow, ${ }^{116}$ a manufacturer of valves and fire hydrants was permitted to make a contribution to Princeton University when the corporation argued that "Capitalism and free enterprise owe their survival in no small degree to the existence of our private, independent universities," and that if American business does not aid in the main-

110. In Nissen v. International Bhd. of Teamsters, 229 Iowa 1028, 295 N.W. 858 (1941), the court held that a union member may not be expelled for refusing to disobey a court order.

111. Spayd v. Ringing Rock Lodge No. 665, 170 Pa. 67, 113 A. 70 (1921) held void a by-law of a union which provided for the expulsion of members who opposed any action of the leadership when it was found that this by-law had been used to abridge the members' freedoin to petition the government. Similarly, Stein v. Marks, 44 Misc. 140, 89 N.Y.S. 921 (Sup. Ct. 1904), held it to be against public policy for a literary society to expel a member for joining a particular political party. But cf. O'Leary v. Rose, 173 Misc. 1092, 19 N.Y.S.2d 704 (Sup. Ct. 1940), whicl permitted a political party to expel a particular cell which had become disloyal.

112. See Jaines v. Marinship Corp., 25 Cal. 2d 721, 155 P.2d 329 (1944), where the court held that a union choosing as its purpose to be a social group could exclude blacks, but that if it chose to represent a closed shop, exclusion of blacks would not be acceptable; the union's economic and social purposes were separate.

113. See generally Hearings, supra note 5 .

114. See, e.g., 6 AM. JUR. 2d Associations and Clubs $\$ 5$ (1963).

115. Developments in the Law-Judicial Control of Actions of Private Associations, 76 HARv. L. Rev. 983, 1016 (1963). The Comment suggests that there should be limits to the association's ability to redefine itself when a member may be harmed by such an action and that a court should be willing to weigh the imterests of the group against the interests of the dissident members. Also of interest is Chafee, The Internal Affairs of Associations Not for Profit, 43 HARv. L. Rev. 993 (1930).

116. 13 N.J. 145, 98 A.2d 581, appeal dismissed, 346 U.S. 861 (1953). This case is cited and discussed in Lattin, Jennings, \& Buxbaum, Cases and Materials on Corporatrons 200 (1968) which also cites a compilation of similar cases in 1 A.B.A. A.I.I., MODEL Bus CORP. ACT 141-42 (1960) and 60-61 (1966 Supp.). See also Prunty, Love and the Business Corporation, 46 VA. L. Rev. 467 (1960); Note, How Far Corporations May Contribute to Charity, 35 VA. L. Rev. 401 (1949). 
tenance of private universities it is not "properly protecting the longrange interests of its stockholders, its employees, and its customers."117 Corporate support is, however, limited in amount; the corporation may not inake such a large contribution as would constitute a spoliation of the corporate assets, ${ }^{118}$ and as the amount becomes imcreasingly significant the contribution is subject to attack as one which is made not for the welfare of the corporation, but rather to support a pet charity of management. ${ }^{119}$

Private colleges are a liybrid and may or may not be governed by the rules discussed above, depending on whether their activities are seen to involve state action, and are thus limited by the first and fourteenth amendinents. ${ }^{120}$ A court might use any one of five theories to characterize the actions of an otherwise private institution as state action. ${ }^{121}$ First, it may be found unconstitutional for the state to disperse funds to a private college engaged in activity that would be constitutionally forbidden the state. ${ }^{122}$ Second, there may be such extensive legislation surrounding the college that it will be held to the same standards as a public college. ${ }^{123}$ A third possibility is that a court might find that the private college was performing a service that would otherwise be performed by the state, and that the state may not deny citizens rights they would liave were the state to fulfill its role. ${ }^{124} \mathrm{~A}$ fourth inode of reaching this decision would be for a court to rejuvenate Shelley v. Kraemer ${ }^{125}$ and hold that while the action of the college

117. 13 N.J. at 148,98 A.2d at 583 .

118. See generally articles cited note 116 supra.

119. Id.

120. The leading older cases which found that the receipt of public funds by a private educational institution did not transform the collcge into a state agency are: Allen v. McKean, 1 F. Cas. 489 (No. 229) (Cir. Ct. Me. 1833); Board of Educ. v. Greenebaum, 39 I11. 609 (1864); Board of Educ. v. Bakewell, 122 I11. 339 (1887); Orono v. Sigua Alpha Epsilon Soc., 105 Me. 214, 74 A. 19 (1909); State ex rel. Clark v. Maryland Institute, 87 Md. 643, 41 A. 126 (1898). More recent cases have sphit on this issue. See Note, An Overview: The Private University and Due Process, 1970 DURE L.J. 795.

The continuance of two opposing lines of cases suggests that the issue of state action has been masking a policy determination by the court as to when it is willing to interfere with the administration of private schools. See O'Neil, Private Universities and Public Law, 19 Buffalo L. Rev. 155 '(1970). Compare Griffin v. State Bd. of Educ., 239 F. Supp. 560, 565 (E.D. Va. 1965) (finding that there was state action when tuition grants were made which tended to pronote racial segregation) with Browns v. Mitchell, 409 F.2d 593 (10th Cir. 1969) (refusing to find state action when the issue was suspension of students for disciplinary reasons.)

121. See generally Developments in the Law-Academic Freedom, 81 Hanv. L. REv. 1045, 1056-61 (1968).

122. Griffin v. State Bd. of Ednc., 239 F. Supp. 560 (E.D. Va. 1965).

123. Cf. O'Neil, Private Universities and Public Law, 19 Bufralo L. REv. 155 (1970).

124. See, e.g., id. at 176-79.

125. 334 U.S. 1 (1948). 
was in fact not state action, judicial enforcenent of private action forbidden the state would be. ${ }^{128}$ Finally, the court might find that, while no one of the previous four theories is alone sufficient to find state action, in sun there has been state action. ${ }^{127}$

There seems to be no principled way to distinguish between state and private action in the area of education. In light of this difficulty, students at a private university seeking to establish a nembership supported firm can only be certain of not raising the unresolved first amendment issue of forced contributions if they use a refundable fee.

\section{CoNCLUSION}

Meinbership support offers an exceptional opportunity to raise the necessary funds to establish a law firm, and inembership support provides a constituency to which the firm can be responsible and froin which it can draw non-1nonetary support. By banding together to fund a membership supported law firm, minority imterest groups can obtain legal representation to protect their group interests or the broader public interest. Public universities and similar organizations whose activities involve state action nay assess their meinbers to support a firm without violating the Constitution if such support can be characterized as being within the general purposes of the association. These firms cannot be opposed because of possible problems of legal ethics. Membership supported law firms have been to a large extent children of the state's effort to open the legal process to problems which have heretofore been denied legal redress. As such, the mere possibility of a conflict of interest bewteen the firm and individual chents is not of sufficient weight to warrant broad prohibitions which, in the name of protecting the interests of the clients, would cripple their efforts to be heard.

Palmer Brown Madden

126. Because of its broad sweep, this theory has been out of favor almost since it was handed down. A majority of the Court has used it only once subsequently. Barrows v. Jackson, 346 U.S. 249 (1953). Its continued vitality is in doubt. See Evans v. Abney, 396 U.S. 435 (1970).

127. See Burton v. Wilmington Parking Authority, 365 U.S. 715 (1961). 